\title{
MUNICIPAL INSOLVENCY: THE NEW CHAPTER IX OF THE BANKRUPTCY ACT
}

\author{
LAWRENCE P. KING*
}

On April 8, 1976, the most recent amendment to Chapter IX of the Bankruptcy Act was enacted into law and became effective. ${ }^{1}$ It replaced sections 81-84 of the Act which Congress had enacted in 1937. ${ }^{2}$ Subsequently, the Supreme Court of the United States adopted a revised set of Chapter IX Rules and Official Forms and forwarded them to the Congress: ${ }^{3}$ The rules and forms became effective on

* Murry and Ida Becker Professor of Law and Associate Dean, New York University School of Law.

THE FOLLOWING CITATIONS WILL BE USED IN THIS ARTICLE:

Bankruptcy Act, ch. 541, 30 Stat. 544 (1898), codified as amended at 11 U.S.C. $\S \S 1$ et seq. (1970) [hereinafter cited as Act, or cited by relevant chapter number];

Act to Amend Chapter IX of the Bankruptcy Act, Pub. L. No. 94-260, 90 Stat. 315, amending 11 U.S.C. $\$ \$ 401$ et seq. (1970) [hereinafter cited as Chapter IX Amendment, or cited by relevant section number];

Chapter IX Rules and Official Chapter IX Forms, reported in Supreme Court Reporter, vol. 96, no. 15, at 43 (June 1, 1976) [hereinafter cited as RuLEs, or cited by relevant Rule number];

CONFERENCE REPORT TO ACCOMPANY H.R. 10,624, H.R. ReP. No. 94-938, 94th Cong., 2d Sess. (1976) [hereinafter cited as CoNF. REP.];

Report on H.R. 10,624, H.R. ReP. No. 94-686, 94th Cong., 2d Sess. (1976) [hereinafter cited as H.R. REP.];

REPORT ON S. 2597, S. REP. No. 94-458, 94th Cong., 1st Sess. (1975) [hereinafter cited as S. REP.].

1. Pub. L. No. 94-260, 90 Stat. 315 (April 8, 1976).

2. 11 U.S.C. $\$ \$ 401$ et seq. (1970).

3. Rules. Prior to the amendment, the Advisory Committee on Bankruptcy Rules of the Judicial Conference of the United States had prepared rules of procedure for Chapter IX. The draft rules had been submitted to the bench and bar for comment, were finally approved by the Advisory Committee, and had been submitted to the Standing Committee on Rules of Practice and Procedure for its approval. The Standing Committee had forwarded the rules to the Judicial Conference of the United States which in turn, after approving them, forwarded them to the Supreme Court of the United States for promulgation. Accordingly, during the period when Congress was considering an amendment to Chapter IX, the rules which had been drafted pursuant to Chapter IX as it had existed since 1937 were sitting with the Supreme Court but had not yet been promulgated. When it appeared likely that Congress would pass the amendment to Chapter IX, the Advisory Committee revised the rules in light of the amendment and, following the same process of obtaining approval from the Standing Committee and the Judicial Conference, the revised set was submitted to the Supreme Court as a substitute for the prior set. The revision of the rules was obviously necessary in light of the change in the statute. For the most part, the revised set of rules follows very closely the procedural portions of the amended Chapter. Where there is conflict between the 
August 1, 1976. Thus, the source of substantive law and procedural rules governing a municipal insolvency is now found im Chapter IX of the Bankrupcy Act and in the Chapter IX Rules.

The amendment to Chapter IX was necessitated by a recognition that the version in existence did not serve the purposes for which it was intended. The fiscal crises in New York and other cities arising during the summer and fall of 1975 showed clearly that Chapter IX, as it existed in the Bankruptcy Act, was not realistically available to major public entities. A simgular difficulty with respect to sections 8184 was the requirement that, in order to commence a proceeding under Chapter IX, the petitioner had to file at the outset a plan which had been agreed to by a majority (in dollar amount) of creditors affected by the plan. ${ }^{4}$ This meant that before a petition could be filed the municipality had to draft a plan, negotiate that plan with creditors, and obtain consents. All of this is a time-consuming process which makes it virtually impossible to obtain speedy rehef. Additionally, it was recognized that many of the creditors who would be affected by the plan were holders of bonds in bearer forn. Thus, it was impossible to determine the identity of such creditors and obviously, therefore, impossible to negotiate and obtain the necessary consents. ${ }^{5}$ In response to these concerns the 1976 amendment contains many improvements designed to simplify and expedite Chapter IX proceedings and to remove these practical impediments to their use.

\section{The Requirements for Relief}

Section 84 sets forth the requirements for seeking relief under Chapter IX. Certain facts must be alleged in a petition filed under Chapter IX; ${ }^{\circ}$ these facts must also be proven at a hearing if the petition is contested. ${ }^{7}$ First, the political subdivision, public agency or instrumentality must allege that it is generally authorized by state law to file a petition under Chapter IX. This provision stems from two Supreme Court decisions of the 1930s, one of whicl declared a predecessor statute unconstitutional ${ }^{8}$ and the second of which upheld a revision of

rules and the amended Chapter, the rules control; pursuant to 28 U.S.C. $\$ 2075$ (1970), the rules have the effect of superseding those procedural provisions.

4. See 11 U.S.C. $\$ 403$ (1970), as amended, Act $\S 83$.

5. See Conf. Rep. 17.

6. See Official Chapter IX Form No. 9-F1, reprinted in Supreme Court Reporter, vol. 96, no. 15 at 69-70 (June 1, 1976), (entitled "Chapter IX Petition" and incorporating the requisite allegations and statements).

7. See notes 25-27 infra and accompanying text.

8. Ashton v. Cameron County Water Improvement Dist. No. 1, 298 U.S. 513 (1936). The district had filed an insolvency petition under the Act of May 24, 1934, 
that statute. 9 One of the factors upon which the Court relied in finding the revised law constitutional was the provision in that statute which left to the states the power to determine whether their agencies and subdivisions could make use of the federal bankruptcy statute. ${ }^{10}$ Until enactment of the 1976 amendment, Chapter IX did not contain the requirement that a governmental entity be authorized under state law to file a petition. The omission of such a requirement from the chapter, viewed in light of these Supreme Court decisions, led to the conclusion that a petition could be filed unless the petitioner was expressly prohibited from utilizing Chapter IX. In other words, prior to 1976 , affirmative authorization was not required, but the states could enact legislation which would prohibit their subdivisions or agencies from utilizing the Bankruptcy Act. ${ }^{11}$

In the drafting of the 1976 amendment, this approach to the authorization question was recognized as one of the possibilities. At the other extreme, some thought was given to requiring specific state authorization for the filing of such a petition. ${ }^{12}$ This would mean that in advance of filing a petition there would have to be a state enactment which would authorize that particular subdivision, agency or in-

ch. 345, $\S$ 78-80, 48 Stat. 798, captioned "Provisions for the Emergency Temporary Aid of Insolvent Public Debtors . . . ." The statute was invalidated on the grounds that it exceeded Congress' authority to interfere in local fiscal management, and, more specifically, that it operated as an indirect impairment of the states' rights to enter into contracts. 298 U.S. at 530-32.

9. United States v. Bekins, 304 U.S. 27 (1938). Petitioner in this case was a local irrigation district. The petition was filed under Chapter X of the 1937 Amendments to the Bankruptcy Act, Act of August 16, 1937, ch. 657, 50 Stat. 653. Ashton was distinguished on the basis that the new Chapter $X$ was

carefully drawn so as not to impinge upon the sovereignty of the State. The State retains control of its fiscal affairs. The bankruptcy power is exercised in relation to a matter normally within its province and only in a case where the action of the taxing agency in carrying out a plan of composition approved by the bankruptcy court is authorized by state law. It is of the essence of sovereignty to be able to make contracts and give consents bearing upon the exertion of governmental power. 304 U.S. at 51-52.

10. Id.

11. See, e.g., Faitoute Iron \& Steel Co. v. Asbury Park, 316 U.S. 502, 508-09 (1942); Mission Independent School Dist. v. Texas, 116 F.2d 175 (5th Cir. 1940), cert. denied, 313 U.S. 562 (1941).

12. The House bill provided only that an entity must not be prohibited by state law from filing a Chapter IX petition. H.R. 10,624, 94th Cong., 1st Sess. $\$ 84$ (1976). "The reference to a prohibition by state law recognizes a limitation frequently expressed in the cases and literature." H.R. REP. 20, citing Faitoute Iron \& Steel Co. v. Asbury Park, 316 U.S. 502 (1942); see 5 W. COLlIER, BANKRUPTCY \ 81.04 (14th ed. rev. 1976); Note, A Survey of Municipal Bankruptcy Law and Procedure, 38 BRookLYN L. REv. 478, 485-87 (1971). The Senate bill required specific authorization. S. 2597, 94th Cong., 1st Sess. $\S 803$ (a) (1975). The Senate Report is somewhat ambiguous on this point. It states: 
strumentality to commence a proceeding under Chapter IX. The final version of section 84 reaches what might be termed a compromise solution or middle ground. It provides that there must be general authorization to file a petition under Chapter IX. ${ }^{13}$ The general authorization can be accomplished by state legislation at any time; it need not be enacted specifically in response to a particular situation.

Even with the less stringent requirement of general authorization, problems may occur. For example, a financial crisis may arise which had not been contemplated previously. At the time when a state agency must or should make use of Chapter IX such general authorization may be lacking, and the legislature may not even be in session. Accordingly, there may be time wasted in attempting to get the legislation; at worst, it may simply be impossible for that particular agency to get the requisite authorization to use Chapter IX. It would have been better had the prior law of "prohibition" been retained in the amended version of Chapter IX. The states would have retained the power to determine whether they should permit their subdivisions, agencies and instrumentalities to utilize the Bankruptcy Act, but without the attendant dilemma of requiring an affirmative act of the legislature which at times may be difficult, either politically or practically, to accomplish.

The second required allegation is that the petitioner is eligible for relief under the chapter, i.e., that it is a proper political subdivision, a public agency or instrumentality. These terms are not defined in the statute. ${ }^{14}$

Third, the petition must allege that the petitioner is insolvent or unable to meet its debts as they mature. Insolvency is defined in section 1 of the Bankruptcy Act, but that section does not necessarily apply in Chapter IX cases. ${ }^{15}$ However, it is reasonable to assume that

The Committee considered it questionable whether the affirmative consent of the state is constitutionally required. If not for constitutional reasons, the Committee believed as a policy matter that such consent should be obtained. A general statutory provision which may have been enacted prior to this Chapter is thought by the Committee to meet the requirement of specific consent. In the absence of general statutory consent, [section] 803 (a) authorizes the chief executive, legislature or any other governmental officer or organizations so empowered under state law, to authorize the filing of such a petition.

S. REP. 16. It would seem that this expression of intent would permit a general as distinguished from a specific authorization.

13. See generally CONF. REP. 16-17.

14. Section $81(8)$ defines "petitioner" to mean an "agency, instrumentality, or subdivision which has filed a petition under this chapter." Section 84 refers to any "State's political subdivision or public agency or instrumentality" as being eligible for relief.

15. Chapters X, XI and XIII each contain a general provision incorporating the sections in Chapters I-VII of the Act. See 11 U.S.C. $\$ \$ 502,702,1002$ (1970). No com- 
the definition of insolvency contained in section 1 (the balance sheet test $)^{16}$ would be applicable, as well as the equity definition of insolvency which is expressly incorporated into section 84 by the provision regarding inability to meet debts as they mature.

Fourth, the petition must allege a desire to effect a plan to adjust the petitioner's debts. This would of course present no difficulty by way of allegation or proof.

Finally, the petitioner must allege at least one of the four alternatives set forth in clauses (1) through (4) of section 84. These alternatives are:

(1) that petitioner successfully negotiated a plan with creditors holding at least a majority in amount of claims; or

(2) that petitioner negotiated in good faith but was unable to obtain the agreement of at least a majority of such creditors; or

(3) that such negotiation is impracticable; or

(4) that petitioner has a reasonable fear that a creditor may attempt to obtain a preference.

These clauses also represent a compromise between two positions. In drafting the amendment, one thought was to eliminate any restriction with respect to the filing of a petition under Chapter IX, recognizing that under the prior version it was extremely difficult to make use of the cliapter because the petition had to be accompanied by the plan and the necessary consents. ${ }^{17}$ Another clioice would liave been to retain stringent requirements in order to "limit accessibility to the bankruptcy court somewhat."18 The requirement for a pre-petition plan and agreement of creditors is retained im clause 1 of section 84; if that is impossible to obtain, a good faitl attempt to negotiate a plan is recognized as an acceptable substitute. If even that is impossible to accomplish, the statute allows petitioner to allege that negotiation was impracticable under the particular circumstances. A fimding of im-

parable provision was included in amended Chapter IX. Accordingly, only those provisions expressly incorporated are applicable in a Chapter IX case. Section 1, the definitions section of the Act, is not so incorporated.

16. See 11 U.S.C. \$ 1(19) (1970):

A person shall be deemed insolvent within the provisions of this Act whenever the aggregate of his property, exclusive of any property which he may have conveyed, transferred, concealed, removed, or permitted to be concealed or removed with intent to defraud, hinder, or delay his creditors, shall not at a fair valuation be sufficient in amount to pay his debts.

17. See H.R. REP. 6-7.

18. CoNF. REP. 17. It is interesting to note that neither H.R. 10,624 nor S. 2597 as reported out by the respective Committees on the Judiciary contained the requirements that found their way into clauses (1) through (4) of section 84 . The Conference Report does not indicate at whose instigation they were added during conference. 
practicability could presumably be based on insufficient time or the inability to identify the inajor part of the creditors who would be affected by such a plan. The final alternative allegation, which will perhaps be used as a catchall, is that petitioner has a reasonable fear that a creditor may attempt to obtain a preference. Preference is defined by section $60 \mathrm{a}$ of the Act to mean a transfer of a debtor's property to a creditor for or on account of an antecedent debt, made within four months of the filing of a petition under the Act and at a time when the debtor was insolvent, which transfer has the effect of giving to that creditor a greater percentage of its debt than other creditors of the same class would receive. ${ }^{19}$ Under section $84(4)$, petitioner need only allege that it has a "reasonable fear" that some creditor "may" attempt to obtain a preference. This could presumably inean that a creditor is threatening a lawsuit to obtain judgment for the purpose of collecting a debt, or that particular pressure is being placed upon petitioner by a creditor in order to obtain preferential payment of an antecedent debt.

In summary, it should be possible for a political subdivision, public agency or instrumentality of a state to make use of Chapter IX by alleging either that negotiation of a plan is impracticable or that there is in existence some creditor who is threatening to obtain a preference.

\section{Procedure Under Chapter IX}

Rule 9-11, read in conjunction with section 85(a), specifies the procedural steps to be taken at the very beginning of a Chapter IX case. When a petition is filed, the court is directed, under Rule 9-11(a), to enter an order approving the petition if it is satisfied that the petition coinplies with the requirements of Chapter IX and has been filed in good faith. That order may be entered ex parte or the court inay hold a hearing. Such an order is considered only a preliminary approval of the petition, because it does not foreclose the possibility that a party in interest may file an answer to the petition and that the court may subsequently find the petition to have been improperly filed. ${ }^{20}$ Even in determining whether preliminary approval should be given, the court is not bound to issue an immediate adjudication; if it is not satisfied that the petition complies with Chapter IX

19. Since section 84(4) refers merely to "preference," only the provisions of section $60 \mathrm{a}$ of the Act are incorporated. Section $60 \mathrm{~b}$ is excluded. That subsection makes a preference (as defined in section 60a) voidable if the creditor receiving it had reason to know of the debtor's insolvency.

20. See notes 25-27 infra and accompanying text. 
or that it has been filed in good faith, the court may permit the petition to be amended. Finally, of course, the court may dismiss the case.

After preliminary approval is given, the court is to set a date for a meeting of creditors, which is to be held not less than 30 nor more than 90 days after such approval. ${ }^{21}$ Pursuant to section $85(\mathrm{~d})$ and Rule 9-14(a), at least 30 days' notice must be given by mail to creditors whose names and addresses appear on a list filed with the court. ${ }^{22}$ This notice must also be published "at least once a week for 3 successive weeks in at least one newspaper of general circulation published within the district in which the case is pending, and in such other paper.... [of] general circulation among bond dealers and bondholders as may be designated by the court."23 Publication of the notice must begin as soon as practicable after the filing of the petition and must be completed at least 30 days before the date fixed for the meeting. ${ }^{24}$

Chapter IX can be used on a voluntary basis only. While a voluntary petition may be filed by an eligible governmental entity, the chapter contains no provision by which a creditor may force a government body into involuntary bankruptcy. Pursuant to section 85(a) and Rules 9-10 and 9-11, however, creditors and other parties in interest may object to a petition. Any party in interest may serve and file an answer to a petition within 15 days of the completion of publication of notice. ${ }^{2 \pi}$ The answer must contam all defenses and objections, including any which may be raised by separate motion under Rule 12(b),(e), or (f) of the Federal Rules of Civil Procedure. ${ }^{26}$ If such an answer is filed in timely fashion, Rule 9-11(h) requires that the court hold a hearing on the answer and petition either at the meeting of creditors or at such earher time as it may fix. The court may dismiss the petition after hearing if it finds that the petitioner did not file the petition in good faith or if the petition does not meet the requirements of Chapter IX. ${ }^{27}$ The case may also be disposed of by the issuance of "such other order as may be appropriate."28 Permission to amend the petition may constitute an appropriate alternative order under some circumstances. ${ }^{29}$

21. Rule 9-17.

22. Rule 9-7 requires the petitioner to file a list of creditors of each class containing their names and addresses, the amount of their claims and the character of their claims.

23. Rule 9-14(h)(1).

24. Id. These provisions of the Rule are derived from section 85(d).

25. Section 85(a); Rule 9-10(a).

26. Rule 9-10(b).

27. Section 85(a).

28. Rule 9-11(b).

29. See Rule 9-11(a). 
It is apparent that between the filing of the petition and entry of an order after hearing (if the petition is contested), some activity may have occurred in the case. It is further apparent that there may be an appeal from the order issued. Accordingly, section 85(a) provides that "[t]he reversal on appeal of a finding of jurisdiction shall not affect the validity of any certificate of imdebtedness authorized by the court and issued in such case." This provision protects third parties who inay have dealt with the petitioner by purchasing or lending against a certificate of indebtedness and also, of course, makes it possible for the petitioner to obtain einergency financing, when appropriate, at the very beginning of the case. ${ }^{30}$

Confusion may arise concerning the court before which Chapter IX cases will proceed. Unlike other proceedings under the Bankruptcy Act, the bankruptcy court has no role whatsoever to play in a Chapter IX case, and the function of the bankruptcy judge is extremely linited. ${ }^{31}$ There is no provision in Chapter IX for the appointunent or election of a trustee or receiver to displace, or act with, the existing officials of the petitioner. ${ }^{32}$ When the Chapter IX petition is filed, section $82(\mathrm{~d})$ provides that the Chief Judge of the district court is to

30. For a discussion of certificates of indebtedness, see notes 51-55 infra and accompanying text.

31. Section $81(2)$ defines "court" to mean the "court of bankruptcy in which the case is pending, or a judge of such court." Section 82 (d) refers to the "judge of the district court" who is to conduct the proceeding. Rules 9-38(6) and 9-38(8) define "court" and "judge" to mean "the United States district court or a judge thereof."

The House Report states that the definition in section 1(10) of the Act, which makes the United States district court the court of bankruptcy, was copied into section 81(2); this was meant to render it clear that the Chapter IX case "is to be conducted in the district court, before a district judge, rather than before a referee in bankruptcy." H.R, REP. 15.

The new Rules follow section 87 (a) and provide as follows with respect to reference to the bankruptcy court:

The court may refer any special issue of fact to a referee in bankruptcy for consideration, the taking of testimony, and a report on such special issue of fact, if the court finds that the condition of its docket is such that it cannot take such testimony without unduly delaying the dispatch of other business pending in the court, and if it appears that such special issue is necessary to the determination of the case. A reference to a referee in bankruptcy shall be the exception and not the rule. The court shall not make a general reference of the case, but may only request findings of specific facts. Rule 9-13.

Interestingly, the Commission on the Bankruptcy Laws of the United States proposed that Chapter IX cases be conducted in the bankruptcy court before a bankruptcy judge. See Report of the Commission on the BankRuptcy Laws of the United States, PART II, c. VIII (1973).

32. Two minor exceptions do exist. Under section $85(\mathrm{~h})$, if petitioner refuses to seek recovery of a pre-bankruptcy transfer rendered voidable by that section, the court on application of a creditor may appoint a trustee for that limited purpose. Additionally, the court may appoint a disbursing agent for the purpose of making distribution under a plan. See section 95(b)(1)(B); Rule 9-27(c)(1). 
notify the Chief Judge of the court of appeals of that circuit of the fact of the filing. The Chief Judge of the circuit then specially designates a district court judge to conduct the proceedings. Thus, the judge selected to conduct the proceedings is not picked at random as in an ordinary civil case, but rather by the Chief Judge of the circuit who has the opportunity to review the calendars of the particular judges and to make a selection based on whatever criteria he deems important. Section $85(\mathrm{c})$, the venue provision, requires that a petition be filed in the district in which the petitioner is located. A filing fee of $\$ 100.00$ inust accompany the petition.

\section{The Effect of Filing a Petition}

(1) Stays. Pursuant to section 85(e) and Rule 9-4, the filing of a petition under Chapter IX operates as an automatic stay of various acts and proceedings. ${ }^{33}$ This automatic stay provision in both the statute and the rule is comparable to the automatic stay rules in Chapters X, XI and XII of the Bankruptcy Act. ${ }^{34}$ The Chapter IX automatic stay, however, is somewhat broader in that it applies as well to any attempt to effect a set-off by a creditor of the petitioner.

As do the rules governing other chapters of the Act, Rule 9-4 and section 85 (e) provide for relief froin the stay for any parties affected. ${ }^{\mathbf{3 5}}$ When a coinplaint requesting such relief is filed, the court is directed to set a hearing at the earliest possible date to resolve the issue of whether the stay should continue or be modified, terminated or conditioned. Absent any modification of the stay it will continue until the case is closed or dismissed or, if it affects property subject to a lien, until that property is abandoned or transferred with the approval of the court. ${ }^{36}$

The effect of the automatic stay provision is to make it unnecessary for the petitioner to initiate a proceeding in the district court to stay any of the acts or proceedings encompassed by section 85(e) and

\footnotetext{
33. Rule 9-4(a) provides:

A petition filed under Rule 9-3 shall operate as a stay of the commencement or the continuation of any court or other proceeding against the petitioner or any officer or inhabitant thereof, which seeks to enforce any claim against the petitioner, or of any act or the commencement or continuation of any court or other proceeding to enforce a lien on the property of the petitioner or a lien on or arising out of taxes or assessments due the petitioner, and shall operate as a stay of the enforcement of any setoff or counterclaim relating to a contract, debt, or obligation of the petitioner.
}

34. See Chapter X Rule 10-601; Chapter XI Rule 11-44; Chapter XII Rule 12-43.

35. Section 85(e)(3); Rule 9-4(c).

36. Section 85(e)(2); Rule 9-4(b). 
Rule 9-4. Provision is made, however, for obtaining other injunctive relief when necessary, with notice and hearing and for cause shown. ${ }^{37}$

Related to the automatic stay are two provisions in Chapter IX of the Act which have no counterpart in any other chapters in the Bankruptcy Act. Section 85(f) provides that an ipso facto clause in a contract or lease is unenforceable. That is, a provision in a contract or lease which permits a party to terminate that contract or lease in the event of the insolvency of the petitioner or the commencement of a proceeding under Chapter IX is not enforceable, subject to the condition that any prior defaults are cured and adequate assurance of future performance is provided. Thus the petitioner would have the opportunity to reinstate a defaulted contract or lease.

Section $85(\mathrm{~g})$ provides for the recovery of a pre-petition set-off asserted by a creditor of the petitioner. This section supplants section 68 of the Bankruptcy Act for practical purposes by providing that any set-off which was effected within four months prior to the filing of the petition is voidable and recoverable by the petitioner after hearing on notice. $^{38}$ A bank which has been holding funds of the petitioner may accordingly be required to return any set-off which it has made against a debt owing to it within four months prior to the petition. Section $85(\mathrm{~g})$ does afford some protection for the creditor who inay have to reverse a set-off by providing that "[ $t]$ he court may require as a condition to recovery that the petitioner furnish adequate protection for the realization by the person against whom or which recovery is sought of the claim which arises by reason of the recovery." That protection may be accomplished in suitable instances by providing for some priority in the plan itself at the later stages of the Chapter IX case. ${ }^{39}$

(2) Avoiding powers. Section $85(\mathrm{~h})$ is new to Chapter IX al-

37. See section 85(e) (4); Rule 9-4(d).

38. Conversely, section 68 recognizes the right to set off mutual debts and credits in ordinary bankruptcy cases. Set-off under section 68 was disallowed in a railroad reorganization case, Baker v. Gold Seal Liquors, Inc., 417 U.S. 467 (1974). See H.R. REP. $2-3,23$.

39. The House Report indicates that if the effect of recovery is to permit petitioner to use collateral, protection should be afforded, but if collateral is not involved protection "might be neither required nor appropriate. The decision in each case is left to the sound discretion of the court." H.R. ReP. 3. Why the report should make such a distinction is not entirely clear. If set-off had been rightfully effected prior to the filing of the petition, any recovery ordered would be of property of the creditor; thus, in either situation a property right or interest may well be affected. The report cites In re Yale Express Sys., Inc., 370 F.2d 433 (2d Cir. 1966), which did not require protection for a secured creditor in a Chapter $X$ case, and In re Bermec Corp., 445 F.2d 367 (2d Cir. 1971), on remand, No. 71-B-291 (S.D.N.Y., July 15, 1971), which required payments to secured creditors representing economic depreciation of their collateral. 
though it is not new to other types of cases under the Bankruptcy Act. For the first time, many of the avoiding powers which permit a petitioner to set aside pre-petition transfers are incorporated within Chapter IX. Under this section, the provisions of sections $60 \mathrm{a}, 60 \mathrm{c}$, $67 \mathrm{a}, 67 \mathrm{~d}, 70 \mathrm{c}, 70 \mathrm{e}(1)$, and $70 \mathrm{e}(2)$, as well as the first three sentences of section $60 \mathrm{~b}$, apply in Chapter IX cases, and for this purpose the label "petitioner" is deemed to be the equivalent of "bankrupt," "debtor," or "trustee."

Section $60 \mathrm{a}$ and the first three sentences of section $60 \mathrm{~b}$ defime a voidable preference and make a transfer coming within the definition of that term voidable at the instance of a trustee. ${ }^{40}$ Thus, the petitioner in a Chapter IX case may, if it can prove all of the elements of a voidable preference as set forth im those sections, set aside a prepetition transfer.

Section 67 a renders voidable a judicial lien obtained withm four months of the filing of a petition under the Act at a time when the debtor was insolvent. Accordingly, a judicial lien obtained under similar circumstances against a Chapter IX petitioner is also voidable at its instance. ${ }^{41}$

Sections $67 \mathrm{~d}$ and $70 \mathrm{e}$ as incorporated in Chapter IX permit the setting aside of fraudulent conveyances and transfers. Section $67 \mathrm{~d}$ is the Bankruptcy Act's version of the Uniform Fraudulent Conveyance Act. It makes a fraudulent conveyance as defined in that section voidable if it occurred within one year prior to the filing of the petition. Section $70 \mathrm{e}$ does not defme a fraudulent conveyance but rather incorporates the applicable state law regarding fraudulent conveyances and other types of conveyances voidable by creditors. It permits the petitioner to succeed to the rights of any creditor with a provable claim

40. A voidable preference is a transfer of a bankrupt's property to a creditor for or on account of an antecedent debt which occurs within four months prior to the filing of a petition in bankruptcy and at a time when the bankrupt was insolvent. It is also required that the creditor had reason to know of the debtor's insolvency and that the effect of the transfer was to give that creditor a greater percentage of his debt than other creditors in the same class would receive. Sections $60 \mathrm{a}, 60 \mathrm{~b}$. It should be noted that because it incorporates the section $60 \mathrm{~b}$ requirement that the creditor have reason to know of the bankrupt's insolvency, the definition of "preference" under section $85(\mathrm{~h})$ differs from the one found in section 84(4) (setting forth standards of eligibility for filing under Chapter IX). See note 19 supra.

"Transfer" is broadly defined in section $1(30)$ of the Act to include involuntary transfers, and creation of liens and security interests. That definition would presumably be applicable for purposes of a Chapter IX case.

41. This section is unlikely to be used when petitioner is a mnnicipality. Judicial liens against pnblic property will rarely if ever be obtained, whether through the attachment or judgment process. 
relative to a pre-bankruptcy transfer. If a creditor with a provable claim $^{42}$ has the right, under state law, to set aside a pre-bankruptcy transfer, that right passes to the petitioner.

Section $70 \mathrm{c}$ is the "strong-arm" provision. It gives to a trustee in bankruptcy the rights of a judicial lien creditor as of the date of the filing of a petition..$^{43}$ Pursuant to section $85(\mathrm{~h})$, the petitioner would have the same status. That status is a hypothetical one and arises only as of the date of the filing of the petition commencing the case. What those rights are with respect to a particular transfer would normally be determined by applicable state law. For example, assume a pre-petition transfer which could be perfected against judicial lien creditors under state law only if some act (e.g., recordation) were done. If that act had not been performed by the date of the filing of the petition, section $85(\mathrm{~h})$ would allow the petitioner, succeeding to the rights of a hypothetical judicial lien creditor on that date, to avoid the transfer.

Whether any of these avoiding powers will have real utility in a Chapter IX case commenced by a municipality remams to be seen. It is difficult to perceive, for example, how the petitioner could have made a conveyance that would have been fraudulent under section 67d. Voidable preferences may conceivably have occurred, although it is relatively unlikely. ${ }^{44}$ Section $70 \mathrm{c}$, in the normal case involving private debtors, applies mostly to unperfected security interests. Those transfers normally do not arise in the case of a municipality; it is therefore not likely that section $70 \mathrm{c}$ will be utilized to any great extent. It was felt, however, that for purposes of granting a broad range of powers it was more desirable to imclude the avoiding powers than to leave them out. ${ }^{45}$

42. "Claim" is defined in section 81(1) to include all claims of whatever character, secured or unsecured, including unliquidated and contingent claims. Section 63 , which defines "provable claims" for ordinary bankruptcy cases, is expressly made inapplicable by section $81(1)$.

43. Under section 70c, the trustee is also given the rights of a hypothetical judgment creditor and of a judgment creditor with execution returned unsatisfied. Normally, a judicial lien encompasses the other two categories and gives greater rights to the creditor.

44. Normally, transfers by public employees with actual intent to defraud creditors or with presumed intent (i.e., for less than a fair consideration when the municipality is insolvent) would not occur. Preferential transfers to creditors could occur by ordinary payments to supply creditors, but it would be unlikely that petitioner would move in a proceeding to recover such payments. Its main purpose is to negotiate a plan; such payments, even if recovered, would not contribute to any significant extent to the funding necessary for the plan. In a financial crisis, note or bond payments would probably be in default, and no payments would be made thereon shortly before the filing of a petition.

45. The incorporation of the avoiding powers was included in the Senate bill but 
Thus, considering all of the provisions in subsections $85(\mathrm{e})$ through (h), it can be seen that the court and the petitioner are given a wide range of powers to deal with the property of the petitioner and any pre-petition transfers.

(3) Rehabilitative provisions. In addition to the powers mentioned above, Chapter IX now includes two provisions taken from other rehabilitative chapters of the Act. These provisions, listed in section 82, serve the general purpose of making rehabilitation more feasible. Subsection $82(\mathrm{~b})$ provides in its first paragraph for the rejection of executory contracts. Such a provision is not new to the Bankruptcy Act; similar measures appear in Chapters X, XI and XII. ${ }^{46}$ After hearing on notice to the parties to the contracts or leases, a petitioner may be permitted by the court to reject burdensome executory contracts and unexpired leases. Despite the precedent for its use in other parts of the Act, this provision may prove controversial in the Chapter IX context.

In the case of a large mumicipality, for example, labor contracts with public employees may be burdensoine, and in fact a partial cause of the financial distress of the municipality. Although the law is not very settled, there have been decisions involving private corporate debtors, particularly in the Court of Appeals for the Second Circuit, that permitted the rejection of collective bargaining agreenients in Chapter XI cases. ${ }^{47}$ Should any similar attempt be made in a Chapter IX case involving a large municipality, it is quite likely that comparable litigation would arise, but with somewhat different implications. Labor contracts with public employees would generally be governed by state legislation. As mentioned earlier, ${ }^{48}$ one of the characteristics distinguishing Chapter IX from the other chapters in the Bankruptcy Act is its relationship to the constitutional balance between federal and state powers. This relationship is recognized in Chapter IX of the Act by section 83 , which states:

Nothing contained in this chapter shall be construed to limit or impair the power of any State to control, by legislation or otherwise, any municipality or any political subdivision of or in such State in the

not in the House bill. The Senate version was accepted in conference with a few modifications. See CoNF. REP. 19. XII).

46. See sections 116(1) (Chapter X), 313(1) (Chapter XI), 413(1) (Chapter

47. See Brotherhood of Ry. Clerks v. R.E.A. Express, Inc., 523 F.2d 164 (2d Cir.), cert. denied, 423 U.S. 1017 (1975); Shopmen's Local 455 v. Kevin Steel Prod., Inc., 519 F.2d 698 (2d Cir. 1975).

48. See notes 12-13 supra and accompanying text. 
exercise of its political or governmental powers, including expenditures therefor. ${ }^{40}$

In the case of a labor contract, state law may provide that at the expiration or termination for any reason of that contract, the existing terms and conditions of employment shall continue in effect until a new contract is negotiated. If a labor contract is rejected pursuant to section 82(b)(1), questions can arise whether the terms and conditions of the rejected contract continue in effect until a new one is negotiated-questions which involve both the interpretation of state law and the consideration of Congress' authority to affect that law. The rejection of such a contract would normally not be for the purpose of terminating employment but rather for the purpose of seeking different terms and conditions of employment. One might, therefore, expect litigation over whether the labor contract is one that may be rejected and, if it may be rejected, whether the petitioner, with the approval of the court, could unilaterally impose terms and conditions of employment until a new one is negotiated. ${ }^{50}$ Of course, labor contracts are not the only ones which may be rejected under section 82(b) (1). Other contracts, such as leases or supply contracts, may be equally burdensome, but it is unlikely that these would involve the same problems as a labor contract. It should be recognized that an

49. Section 83.

50. A difference of opinion developed within the House Committee on this point. In the majority report it is stated that renegotiation of a rejected contract would have to be in accord with "applicable Federal, State, or municipal law" pursuant to section 83. H.R. REP. 8. "That section does not permit Chapter IX to interfere with or derogate from any State law that regulates the way in which municipalities may execute this governmental function." Id. at 9.

In the Supplemental Views, certain Republican Congressmen expressed disagreement with this interpretation in the following language:

The Committee report indicates that even though executory collective bargaining agreements may be rejected, certain collective bargaining agreement [sic] may have to be renegotiated pursuant to State law and existing terms and conditions of employment would have to be maintained subsequent to rejection because of certain provisions of State law.

Nothing could be further from the truth. No evidence was taken or memoranda of law submitted to the Committee for discussion on that point. No discussion of this matter took place in the Subcommittee or the full Committee. Id. at 57-58.

The view of the minority members then focused on section 83 and pointed out that it was copied from the superseded chapter. The Supplemental Views continue: "It is being retained because of the Committee's reluctance to remove tested language from existing law and has no relevance to the power of the court to permit a petitioning municipality to reject an executory contract." Id. at 58-59.

In the Senate's consideration of the Conference Report, the colloquy on the floor indicates that the Senate agreed with the opinion expressed in the Supplemental View. See 122 Cong. Rec. S4377 (daily ed. Mar. 25, 1976). See also Note, Executory Labor Contracts and Municipal Bankruptcy, 85 YALE L.J. 957, 966-69 (1976). 
"executory" contract is not defined in the Act. ${ }^{51}$

Subsection $82($ b) also provides, in paragraph (2), for the issuance of certificates of indebtedness. This is another provision taken from both Chapters X and XI of the Act, but more directly from Chapter X. ${ }^{52}$ It is recognized that during the pendency of a Chapter IX case, and particularly toward the beginning of that case, the petitioner may require financing in order to maintain its normal operations. The earlier version of Chapter IX supplanted by the 1976 amendinent did not contain any provision with respect to obtaining such financing through the issuance of certificates of indebtedness. Now, a certificate may be issued with permission of the court "upon such terins and conditions, and with such security and priority in payment over existing obligations, secured or unsecured, and over costs and expenses of administration," as the court may allow. ${ }^{53}$ The only priority which is not permitted is over the payment of operating expenses of the petitioner. ${ }^{54}$ If priority is to be given over a secured creditor, or if the certificate is to be secured by a lien which would come ahead of an existing lien, then notice to that secured creditor must be given and a hearing must be held. ${ }^{55}$

As mentioned earlier, the basic purpose of this provision is to create sone possibility for the petitioner to obtain financing. Whether the possibility will exist in a given case depends, of course, on the willingness of banks or other types of lending institutions to provide such financing against a certificate of indebtedness. No doubt with an eye on the then-unfolding fiscal crisis in New York City, Congress gave some thought during the drafting of this legislation to including in the Act the requirement of a federal guarantee for any certificates that might be issued during the pendency of a Chapter IX proceeding. ${ }^{56}$ Naturally, such a guarantee would render any such certificate much more marketable. It was probably recognized, however, that Chapter IX was not being amended exclusively for the benefit of New York City, but would also be applicable to water districts, sewage districts, public agencies, and the like. It would not be desirable to require

51. A definition that may be useful in this regard posits that an executory contract is one in which there is some performance left to be done on the part of both parties to that contract. See Countryman, Executory Contracts in Bankruptcy (pt. 1), 57 Mins. L. Rev. 439, 460 (1973); id. (pt. 2), 58 MinN. L. Rev. 479 (1974).

52. See sections 116(2) (Chapter X), 344 (Chapter XI).

53. Section 82(b)(2).

54. $1 d$.

55. See Rule 9-32.

56. See H.R. REP. 55-56 (separate views of Rep. Holtzman on H.R. 10,624). 
federal guarantees of certificates of indebtedness in all cases; inoreover, the political climate dictated the omission of such a provision.

\section{The Filing Process}

The claim filing procedure under Chapter IX is a simplified one derived from the Chapter X Rules. ${ }^{57}$ Under the Act and Rules, ${ }^{58}$ the petitioner is required to file a list of creditors with their addresses and the amounts of their claims. As unknown creditors become known, the petitioner is required to file supplemental lists. A creditor whose claim is listed by the petitioner need not file a proof of claim unless the listed claim is designated as disputed, contingent or unliquidated as to amount. ${ }^{50}$ If a claim is so listed, notice nnust be given to the creditor of that fact, and of the time by which the creditor must file a proof of claim. ${ }^{60}$ The court may order that all proofs of claim be filed and it may set a time for such filing. ${ }^{01}$ In the absence of any objection to a proof of claim, that claim is deemed allowed. ${ }^{62}$

\section{Approval of the Plan}

The claim procedure is keyed into the vote necessary for the acceptance of a plan proposed by the petitioner. Creditors with claims that have been deemed allowed or that have in fact been allowed may vote on a plan pursuant to section 92. Under section 92(b), a plan must be accepted in writing by creditors holding at least two-thirds in amount of claims of each class and more than $50 \%$ in number of the claims of each class. The two-thirds and simple majorities required for confirmation are computed, under section 92(c), on the basis of the votes which are in fact cast. ${ }^{03}$ This represents a departure from the prior law. Previously, a creditor whose claim was filed and allowed did not have to vote to reject a plan. ${ }^{64}$ A failure to vote counted as a rejection. Under Chapter IX as amended, in order to reject a plan a creditor must cast a ballot.

57. See Chapter X Rule 10-401.

58. See section 85(b); Rule 9-7. See note 15 supra.

59. Rule 9-22(a) (derived from section 88(a)).

60. Section 88(a); Rule 9-22(b)(3)(A).

61. See section 88(a); Rule 9-22(b)(1).

62. Section 88(a); Rule 9-22(e).

63. See also Rule 9-25(c). One who does not vote at all is not counted in any respect. This method of computing the requisite majorities was derived from Chapter $\mathrm{X}$ Rule 10-305(e).

64. Compare 11 U.S.C. $\$ 403$ (d) (1970), with section 92(e). 
The petitioner may file a plan along with its petition or at such later time as the court fixes. ${ }^{65}$ When the plan is filed, it is to be transmitted to creditors together with notice of the period withm which the plan may be accepted or rejected. The plan may be accepted or rejected prior to the conclusion of the meeting of creditors. ${ }^{66}$ A summary of the plan may be transmitted to creditors in substitution of the full plan itself, but if a creditor requests a copy of the plan he is entitled to receive it. ${ }^{67}$

The plan may mclude provisions modifying or altering the rights of secured or unsecured creditors or any class of them. ${ }^{68}$ Objections may be filed to the plan by any party in interest, and by the Securities and Exchange Commission. ${ }^{69}$ After the expiration of the time set for acceptance or rejection of the plan the court is to hold a hearing on confirmation; notice of the hearing and of the time allowed for filing objections is to be given all parties entitled to object. ${ }^{70}$

If a proposed plan has been properly accepted, the court must make independent fimdings for fimal confirmation of that plan. The court must find, for example, that the plan is fair, equitable and feasible, that it complies with the provisions of Chapter IX, that it has been properly accepted, and that the petitioner is not prohibited by law from taking any action necessary to be taken in order to carry out the provisions of the plan. ${ }^{71}$

The fair and equitable and feasible test is perhaps the most important of all of the conditions for confirmation. "Fair and equitable" is taken froin the superseded Chapter and is also found in Chapter $\mathrm{X}$ of the Act. ${ }^{72}$ As construed in Chapter X it incorporates the absolute priority rule. ${ }^{73}$ This normally means that distribution under the plan must be made in accordance with the priority rights of creditors and that no subordinate class may receive anything unless prior classes have received in full that to which they are entitled. In the Chapter X context, this application of the fair and equitable test normally requires valuation of the business on a going concern basis in order to determme

65. See Rule 9-24(a) (derived from section 90(a)).

66. Rule 9-25(a). The meeting of creditors, of course, may be adjourned from time to time. See Rule 9-24(b).

67. Rule 9-24(b).

68. See section 91 .

69. See section 93. The SEC is, however, denied the right to appeal.

70. See section 94(a); Rule 9-27.

71. Section 94(b).

72. See section 221(2).

73. See Case v. Los Angeles Lumber Prods., 308 U.S. 106 (1939); Northern Pacific Ry. v. Boyd, 228 U.S. 482 (1913). 
whether the corporation is insolvent. If it is insolvent, stockholders, for example, are not entitled to receive anything under the plan because they are the lowest category or class of persons in the priority list, and may not receive anything until all creditors have been paid in full.

In a case involving a municipality under Chapter IX, the test would have to be somewhat different. The municipality cannot be valued on a going concern basis because it is not a profit-Inaking enterprise. The fair and equitable and feasible test should more properly involve a comparison between the expenditures and the incoine necessary for the particular municipality, considering in the assessinent of income the extent to which taxes can be raised and obtained. ${ }^{74}$ Feasibility would be determined by ascertaining whether the petitioner is presently, or in the future will be, in a position to carry out the specific provisions of that plan.

The amended chapter also provides for certain priorities which were not included in the previous chapter. ${ }^{75}$ It lists three classes of priorities:

(1) the costs and expenses of administration;

(2) debts owed for services or materials provided within three months before the filing of the petition; and

(3) debts owing to any person which are entitled to priority by the laws of the United States other than the Bankruptcy Act.

The only creditor which would be entitled to a priority under the laws of the United States would be the United States government itself. $^{76}$ Under section 89 , provision for full payment of priority debts must be made in the plan, unless a waiver is executed by the claimant.

\section{Dismissal of Case}

Unfortunately, section $98(\mathrm{~b})$ provides that if confirination is refused the court must disiniss the case. Such disinissal would take the petitioner out of the supervision of the court and probably put it back in the same position it was in before it filed the petition. To obviate this result, a court should to the extent possible refrain froin refusing confirmation but rather should put off a decision on the confirmation issue and perinit the filing of a modified plan in the hope that such a plan could be confinned.

74. See H.R. REP. 32-33.

75. See section 89.

76. 31. U.S.C. $\$ 191(1970)$. 
As distinguished froin dismissing a petition pursuant to an answer filed opposing it, ${ }^{77}$ section 98 (a) provides other reasons for dismissal of the case. Under this section, the case may be dismissed for want of prosecution (1) if a plan is not proposed within the time fixed or extended, (2) if a proposed plan is not accepted within the time fixed or extended, or (3) if the petitioner defaults in any of the terms of the plan or pursuant to the occurrence of a condition specified in the plan. As indicated above, if the court cannot confirm the plan, dismissal is mandatory. Dismissal for these other reasons lies within the discretion of the court.

Finally, section $95(\mathrm{~b})$ provides for the discharge of all claims against the petitioner when a plan has been confirmed and when the necessary deposit has been inade. Claims which are not discharged include those specifically excepted from discharge by the plan or confirmation order and those claims held by persons lacking timely notice or actual knowledge of the petition or the plan.

\section{Conclusion}

As may be seen from this survey of the provisions of Chapter IX as amended and the Rules for Chapter IX, the present statute and rules conform more closely to other rehabilitation chapters under the Bankruptcy Act than did the earher version of Chapter IX. It is certainly contemplated that such conformity will make its use more practical and will assist in the rehabilitation process when a petition is filed by an eligible entity. The amended version was drafted and enacted in a relatively short period of time. While it reflects a very thoughtful and competent undertaking, it is quite possible that some errors may have crept in which will come to light as the statute is used. Naturally, it is the hope of all concerned that it will not have to be used, particularly by any municipality, large or small.

77. See note 20 supra and accompanying text. 
